\title{
William James Morton [1845-1920]: Like Father, Like Son (?)
}

\author{
Antonio Aponte-Feliciano, $M D^{\star}$, Sukumar P. Desai, $M D^{\star \star}$ and Manisha S. Desai, $M D^{\star}$ \\ ${ }^{\star}$ Department of Anesthesiology, UMass Memorial Health Care, Worcester, Massachusetts; ${ }^{\star *}$ Department of Anesthesiology, Perioperative and \\ Pain Medicine, Brigham and Women's Hospital, Harvard Medical School, Boston, Massachusetts
}

\section{Disclosure} funds.

This work was supported by intramural

\section{Manuscript Version Presented at CME Meeting}

The $17^{\text {th }}$ Annual Spring Meeting of the Anesthesia History Association and UT Southwestern Medical Center, April 29, 2011, Grapevine, TX.

\section{Abstract \\ William Thomas Green Morton, the man most commonly associated with the introduction of anesthesia in 1846, fathered William Fames Morton. William fames Morton's contributions to society were substantial. He conducted pio- neering work in radiology, radiation oncology, and therapeutic electricity. He authored numer- ous textbooks and articles, and he was an editor of a journal on human behavior. His expertise on diamond mining led to an error in judgment that resulted in a felony conviction. We examine his career and contributions to society, and consider his career in light of his father, William Thomas Green Morton.}

\section{William James Morton, MD}

\section{Early years}

In 1843, William Thomas Green Morton [1819-1868] married Elizabeth Whitman, the niece of Connecticut congressman Lemuel Whitman. Their first child, William

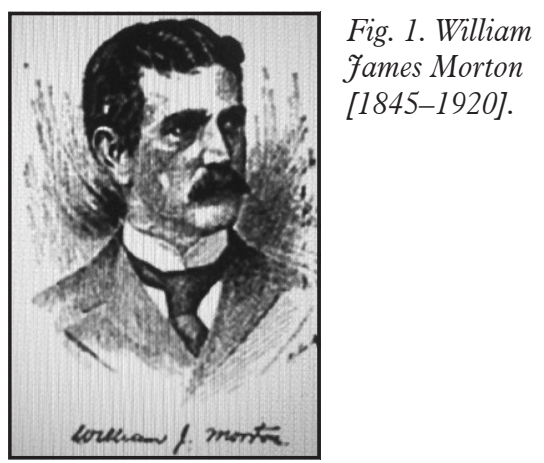

James Morton (Figures 1, 2, and 3), was born on July 3, 1845, in Boston, Massachusetts, ${ }^{1}$ about one year before his father's conclusive public demonstration of the anesthetic effects of ether at Massachusetts General

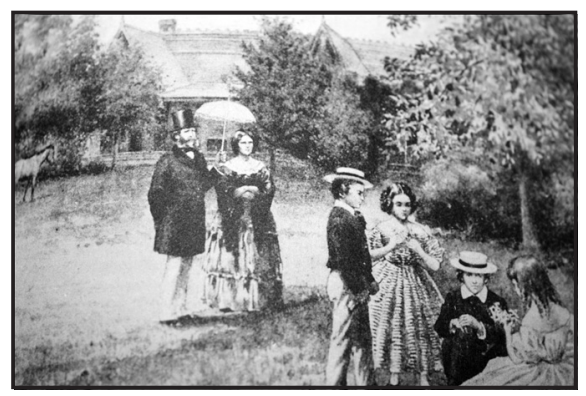

Fig. 2. The William Thomas Green Morton Family at Etherton, in West Needham (currently Wellesley), Massachusetts. The structure was replaced by the Wellesley Town Hall, which was completed in 1886. Reproduced from McClure's magazine, September 1896.

Hospital on October 16, 1846. William James Morton received the best education available. William James Morton graduated from Boston Latin School, the first public school in the United States. Next, he proceeded with undergraduate studies at Harvard College, graduating at age 21 in 1867. For one year, he worked as a principal at a school in Gardner, Massachusetts, after which he began studies at Harvard Medical School. As a medical student in 1872, Morton was awarded the prestigious Boylston Prize for a thesis based on his father's work on the introduction of anesthesia.

After graduating from medical school the same year, he became an assistant in the surgical outpatient department at Massachusetts General Hospital where he later became house surgeon. Next, he moved to Vienna for postgraduate studies related to diseases of the mind and nervous system. His itinerant nature took him next to South Africa in 1876, where he began a profitable mining business, while simultaneously continuing to practice medicine. He learned much about diamond mining in South Africa, and his inquisitive nature and academic skills led him to conduct research. His work entitled South African Diamond Fields: and the Fourney To the Mines was presented at the 1877 annual meeting of the American Geographical Society. In 1878 he relocated to Paris and trained under the famous French neurologist Jean-Martin Charcot [1825-1893].

\section{Clinician and Professional Activities}

William James Morton returned to New York in 1880 to settle down and start a most prolific medical career. The same year, he married Elizabeth Lee, daughter of a prominent coal merchant. His fatherin-law, Mr. Washington Lee, presented the newlyweds with a substantial house at 36 West $56^{\text {th }}$ Street in New York City (Figure 4). Morton's medical office and treatment chambers were located on the first floor, while the family lived on the upper floors. ${ }^{2}$ The couple did not have any children, and in later years Morton married Ellen Komizer [1891-1953], who was 46 years his junior. Upon her death, she willed that her estate, amounting to $\$ 105,000$, be bestowed on her three nieces. It does not appear that they had any children.

Morton's career was remarkable not only due to an extremely busy clinical practice, but also because of his academic activities and leadership positions at professional societies. He served as president of the Harvard Medical Society of New York City (1893), the American Electro-Therapeutic Association (1893), and the New York Neurological Society (1894). Furthermore, he was an active member of the following professional societies: New York State and County Medical Societies, New York Academy of Medicine, Massachusetts Medical Society, American Neurological Association, Harvard Medical Alumni Association,

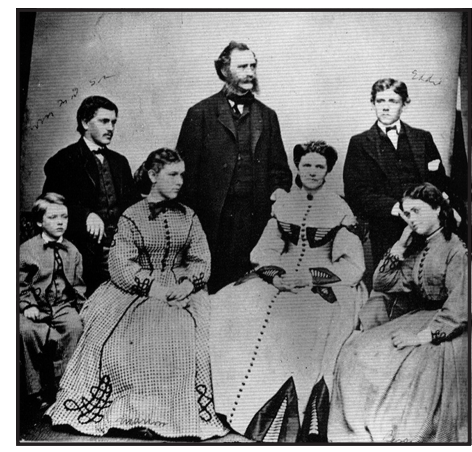

Fig. 3. William Thomas Green Morton and his family. William Fames Morton is shown second from the left. Reproduced with permission, (C) 1962 by Grace Steele Woodward.

Continued on Page 19 


\section{Son... Continued from Page 18}

American Medical Association, Congress of American Physicians and Surgeons, Société Française d'Électro-Thérapie, Boylston Medical Society, University Club of New York, New York Electrical Society, American Geographical Society and the Roentgen Society of London. ${ }^{1} \mathrm{He}$ was simultaneously pursuing disparate interests in clinical medicine, geology, mining, and electricity.

\section{Research and Publications}

In 1882, he bought and became editor of one of the oldest scientific journals on human behavior, the Fournal of Nervous and Mental Diseases. ${ }^{1}$ He remained editorin-chief until 1885, and it is not known when the journal left private ownership. The younger Morton was deeply affected by the fact that his father did not receive proper recognition for his role in publicly demonstrating the efficacy of ether as an anesthetic and for later promoting its use. He remained an avid advocate and defender of his father's claims, and wrote a book entitled Memoranda Relating to the Discovery of Surgical Anesthesia, and Dr. William T.G. Morton's Relation to this Event. He reiterates facts to support his father's claims as the first one to convincingly demonstrate general anesthesia induced with ether. He also discusses facts related to this novel discovery and explains his father's role in the controversy. ${ }^{4}$ Morton did not devote much of his efforts to the study of anesthesia, but he

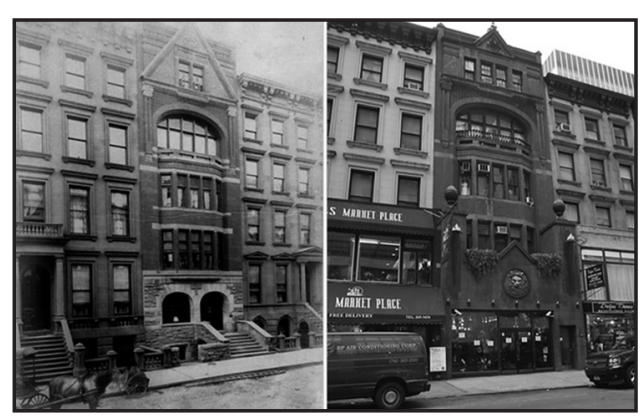

Fig. 4. The William fames Morton Home in 1844 (left), and 2010 (right). Reproduced with permission from the Chicago Art Institute (left) and the New York Times (right).

did explore how local anesthesia by cocaine was influenced by electric current and by mechanical pressure. ${ }^{5,6}$

Luigi Galvani first described the role of electric current in transmission of signals between nerves and muscle in 1791, and Alessandro Volta created the voltaic pile in 1800. Michael Faraday invented the electric motor in 1821, but it was not until the late $19^{\text {th }}$ and early $20^{\text {th }}$ century that electricity found use in daily life and medical treatment. Electrical current was used in the treatment of many diseases, and neurologists such as William James Morton were at the forefront of experimental treatment. He used small currents of electricity to treat several diseases and became famous for treating prominent men, including General John Charles Frémont (1813-1890, US Senator from California, 1850-51, and antislavery war hero), James Gillespie Blaine (1830-1893, US Senator from Maine, 1891, and US Secretary of State, 1889-92). ${ }^{7} \mathrm{He}$ treated president Ulysses S. Grant [1822-85] for carcinoma of the oral cavity, and he also treated President William Henry Harrison's [1773-1841] granddaughter Marthena for scarlet fever in an era when antibiotics were not known.

Once Wilhelm Roentgen discovered xrays in 1895, Morton added an X-ray tube to generate $\mathrm{x}$-rays with his high voltage machine. He started working with x-rays and likely wrote the first American textbook on x-rays, The X-Ray; Or, Photography of the Invisible and its Value in Surgery. ${ }^{8,9}$ This book is the first comprehensive collection of $\mathrm{x}$-ray images taken in the $19^{\text {th }}$ century. He also described the scientific basis behind the generation of these emissions and how they were employed in clinical practice. ${ }^{9} \mathrm{He}$ gave a lecture on $\mathrm{x}$-rays at the meeting of the Medical Society of the County of New York, where he showed live fluoroscopic images of the bones of the hand. ${ }^{10}$ Morton used $\mathrm{x}$-rays for both diagnosis and treatment, thereby becoming one of the pioneers of radiation therapy. In a manuscript describing radiation as a treatment modality, Some Cases Treated by the XRay: Facial Cancer, Carbuncle, Cheloid, Acne, Alopecia Areata, Sychosis, Fibroid Tumor, Psoriasis, Lupus, Primary and Recurrent Carcinoma of the Breast; Artificial Fluorescence of Living Tissue, ${ }^{11}$ Morton heralds the beginning of radiation oncology and presents evidence of successful treatment for cancer.

Morton also treated some diseases using the technique of cataphoresis, a process in which mild electrical current is used to facilitate diffusion of medications through the skin. In 1898, he wrote a textbook about this modality of treatment, Cataphoresis or Electrical Medicamental Diffusion. 5

\section{The Doctors Morton}

In comparing the lives and careers of father and son, we observe many similarities as well as differences. The senior Morton did not complete studies at any medical or dental school, although he is referred to as "Dr. Morton" not only in articles, but also by surgeon John Collins Warren, who remarked wryly, "Doctor, your patient is ready." In March 1849, the father was awarded an honorary degree in medicine by Washington Medical College of Baltimore, Maryland, which existed from 1826 to 1851. The contrast could not be greater with respect to formal education, with the junior Morton receiving the best education available at that time, attending Boston Latin School, Harvard College, Harvard Medical School, Massachusetts General Hospital, performing postgraduate training in Vienna and ending with an apprenticeship with Professor Jean-Martin Charcot. The father, William Thomas Green Morton, and Charles T. Jackson were successful in receiving a patent for "letheon," which was their name for ether (US Letters patent 4,848, November 2, 1846). Vociferous opposition to the patent from the medical and dental communities forced Morton and Jackson to disclose details of their discovery and make it freely available. In 1902, William James Morton received US patent 705,691 for developing a method for dispersing fluids, a technique that continues to have current industrial applications. Although he developed several instruments that were used in clinical medicine, we do not know whether he was unsuccessful in his attempts to secure additional patents, or whether he was not interested in securing them.

The father had many scrapes with the law and was a wanted man in several jurisdictions; however, unlike his son, he was never convicted of a crime and never spent time in prison. A short list of his misdeeds includes swindling Timothy Chapman, Loren J. Ames, Phineas B. Cook, Francis Gorton, and the Sarah Seward Seminary in Rochester, NY; cheating Charles Pomroy, John Creagh, and J.R.W. Keyes in Cincinnati; and taking advantage of N.S. Jacobs and J.B. Sickles and Company in St. Louis. $\mathrm{He}$ was also found in possession of fake US Postal seals and forged bank drafts. ${ }^{3}$ As far as we know, William James Morton committed only one crime and justice was administered swiftly, albeit the presidential pardon softened the blow. This difference may have arisen because individuals were reluctant to pursue William Thomas Green Morton in the courts, or because William James Morton committed a federal crime, which may have made him an easier target.

Although much controversy exists about the individual most deserving of credit for the discovery of anesthesia, William Thomas Green Morton received substantial recognition, albeit posthumously. In his

Continued on Page 20 
Son... Continued from Page 19

later years, he felt robbed of the acclaim for being the founder of anesthesia. A southern senator promoted Crawford Williamson Long as the originator of general anesthesia and had Long's name and image placed on a US postage stamp. The father passed on his bitterness to his son. In contrast, William James Morton does not get well-deserved recognition for his many contributions to the fields of radiology and radiation oncology. Irrespective of these differences, both were restless, innovative opportunists, and men of action.

\section{Felony}

William James Morton's hectic and successful life was marked by one serious error in judgment brought about by an unfortunate association he made with Julian Hawthorne, Albert Freeman, and Josiah Quincy. Hawthorne [1846-1934] was the son of the famous author Nathaniel Hawthorne [1804-1864], Freeman [1852-1938] was vicepresident of the United Mining Company, New York, and Quincy [1859-1919] was a former Mayor of Boston, assistant Secretary of State under President Cleveland, and the great-great-grandson of Josiah Quincy II [1744-1775], also known as "The Patriot." ${ }^{12,13}$ Morton's years in South Africa had taught him not only about the science and technology of mining, but also about the possibility of substantial monetary rewards that accompanied successful exploration.

Morton was hired as a consultant based on his mining expertise. Morton, Hawthorne, and Freeman convinced investors of the potential of finding silver in mines within the "Cobalt Region" in Canada. They falsely claimed, using the vehicle of the United States Postal Service in their solicitations, that cobalt existed in close proximity to silver, and that these mines were an abundant source of silver. They promoted and sold mining interests while claiming yearly revenues of US $\$ 3,500,000$. When in 1912 the mines were found not to contain silver, Morton, Hawthorne, Freeman, and Quincy were put on trial. During their trial, additional testimony was provided that the Hawthorne enterprise had used John D. Rockefeller as bait to draw investors into their illicit activities. ${ }^{14}$ The trio was found guilty on March 14, 1913, of fraudulent activity using the United States

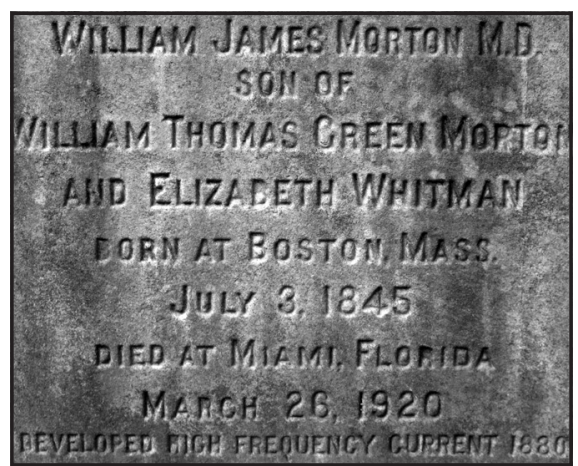

Fig. 5. William Fames Morton's grave at Mount Auburn Cemetery, Cambridge, Massachusetts Reproduced with permission from the Mount Auburn Cemetery.

Postal Service; Morton and Hawthorne were sentenced to a year and a day in the Atlanta Federal Penitentiary, while Freeman was sentenced to 5 years and 3 days. ${ }^{15}$ Morton and Hawthorne were found guilty on 17 counts each, while Freeman was found guilty on 23 counts. Josiah Quincy, who was also mentioned in those activities, was acquitted on one charge of fraud after 28 hours of jury deliberation. ${ }^{12}$ Morton served several months in prison before political connections yielded a presidential pardon by Woodrow Wilson [1856-1924]. Upon release, he successfully petitioned to regain his privilege to practice medicine in New York, and he resumed clinical practice. Morton died of heart disease in Miami on March 26, 1920. ${ }^{12,15}$ It is not known whether he spent his retirement years in Florida or if he was there on a visit. He is buried in the family plot at Mount Auburn Cemetery in Cambridge, Massachusetts, next to his parents (Figure 5).

\section{Conclusions}

William James Morton had an outstanding medical career in New York City, and his skills were highly regarded throughout the United States and Europe. He held academic appointments, initially at University of Vermont and later at New York Post Graduate School, and it is during these years that he conducted pioneering work in radiation oncology and radiology. He was a prolific writer, authoring textbooks in radiology and radiation oncology, as well as scores of scientific articles. Remembering his father's disappointment in obtaining recognition, he always added his own name to any technique or apparatus he described in the literature. We cannot fully explain why he has not found name recognition in these fields. Perhaps his felony conviction influenced the manner in which medical history views him. But Wilhelm Roentgen's original contribution to developing x-rays and Morton's lack of focus probably played a great role in Morton's relative anonymity.

\section{Acknowledgements}

The authors would like to thank Jesse Aronowitz, MD, radiation oncologist at UMass Memorial Health Care, whose assistance was invaluable in uncovering the hidden story behind William James Morton. They would also like to thank the many helpful comments offered by the anonymous reviewers.

\section{Reference List}

1. Spofford AR. 'William James Morton,' in The National Cyclopaedia of American Biography, Volume VIII. New York: James T. White and Co; 1898.

2. Gray C. Where the Gizmos fizzled and the Gin fizzed. The New York Times. January 24, 2010.

3. Wolfe RJ. Tarnished idol - William T.G. Morton and the Introduction of Surgical Anesthesia. San Anselmo, CA: Norman Publishing; 2001.

4. Morton WJ. Memoranda Relating to the Discovery of Surgical Anesthesia. New York: Century Co; 1905.

5. Morton WJ. Cataphoresis or Electrical Medicamental Diffusion. New York: American Technical Book Co; 1898

6. Morton WJ. Pressure anesthesia. Tr N York Odont Soc. 1900;76-91

7. Anonymous. Electricity and disease - Dangers in the use of incandescent current. The New York Times. July 30, 1893.

8. Forrai J. History of the X-Ray in dentistry. Rev Clin Pesq Odontol. 2007; 3: 205-11

9. Morton WJ. The X-Ray; Or, Photography of the Invisible and its Value in Surgery. New York: American Technical Book Co; 1896.

10. Anonymous. The X-Ray in medicine - some experiments made before doctors in this city. The New York Times. April 28, 1896.

11. Morton WJ. Some Cases Treated by the X-Ray: Facial Cancer, Carbuncle, Cheloid, Acne, Alopecia Areata, Sychosis, Fibroid Tumor, Psoriasis, Lupus, Primary and Recurrent Carcinoma of the Breast; Artificial Fluorescence of Living Tissue. New York: William Wood and Company; 1903.

12. Anonymous. Convict three men in Hawthorne case. Jury finds son of novelist, Dr. W. J. Morton, and Albert Freeman guilty of mining frauds. Acquits exmayor Quincy. The New York Times. March 15, 1913.

13. Anonymous. Freeman's appeal wins a new trial. Julian Hawthorne and Dr. Morton, convicted with him, went to prison. The New York Times. August 26,1913 .

14. Anonymous. Rockefeller's name as Hawthorne bait. Oil man suspected of seeking control, investor says he was told. The New York Times. December 27, 1912

15. Anonymous. The end of the Hawthorne case. Engineering and Mining fournal. 1913;95:624-5.

Bulletin of Anesthesia History

David B. Waisel, MD, Editor

Boston Children's Hospital

300 Longwood Avenue - Bader 3

Boston, MA 02115 USA 